INTERNATIONAL JOURNAL OF RESEARCHES IN BIOSCIENCES, AGRICULTURE AND TECHNOLOGY

(c) VISHWASHANTI MULTIPURPOSE SOCIETY (Global Peace Multipurpose Society) R. No. MH-659/13(N) www.ijrbat.in

\title{
ANALYSIS OF WINTER POLLEN LOAD OF DOMESTICATED HONEY BEE, APIS CERANA INDICA FROM SAKOLI TAHSIL OF BHANDARA DISTRICT OF MAHARASHTRA.
}

\author{
Ghugal, S. I. ${ }^{1}$, Bramhankar, K. B. ${ }^{2}$, Rahile, B. S. ${ }^{1}$ and Gedam, P. A. 3 \\ 1. Science Collage Pauni, Distt. Bhandara \\ 2. Hislop College, Nagpur \\ 3. Centre for Sericulture and Biological Pest Management Research, Nagpur
}

\begin{abstract}
:
The present study include 87 pollen loads collected and analysed from 7 combs of domesticated honey bee, Apiscerana indica from Sakoli Tahsil, out of which 61 (70.11\%) pollen load were found to be unifloral, 8 ( $9.19 \%$ ) bifloral and $18(20.68 \%)$ multifloral. In unifloral pollen loads predominant species were found to be Coriandrum sativum, Brassica sp., Sesanum indicum, Cajanus cajan, Lathyrus sativus, Capsicum annum, Alternanthera sessilis and Solanum sp. In bifloral pollen loads predominant species were found to be S. indicum, C. cajan, C. sativum, C. annum, Solanum sp. S. indicus, Brassica sp. While C. sativum, Brassica sp. Parthenium hysterophorus, S. indicum, C. cajan, Prosopisjuliflora, Acassianilotica, Sonchusoleraceus, Tridaxprocumbens, Phaseolus sp. A. sessilis, L. sativus, C. annum and $S$. indicus were the pollen type recorded from multifloral load.
\end{abstract}

Keywords: Pollen load, unifloral, bifloral and multifloral.

\section{INTRODUCTION:}

Melittopalynology helps in seasonal analysis of pollen content in honey and pollen load from given locality. It gives reliable information about availability of major nectar and pollen sources for honey bee (Ramanujam and Khatiza 1992). Nectar and pollen are major food of honey bee. Nectar is source of carbohydrate and pollen are source of protein. Honey is supersaturated balanced sugar solution with many natural sweet substances produced by honey bee from nectar of blossoms or from secretion of other part of the plant which honey bee collected and convert into honey and store in wax comb to ripen (Crane, 1975), pollen load are pollen pellet collected by honey bee in their hind leg.

Microscopic analysis of pollen loads collected by honey bees was performed to determine the sources of pollen for bee colonies. Betts (1935) performed investigations of pollen loads from Apis mellifera L. colonies in England, to find the pollen sources of flowers. Several studies were made later on in Europe, as Synge (1947) and Percival (1947) on pollen loads collected from $A$. mellifera bee colonies in the UK; Louveaux $(1954,1958)$ from France;
Maurizio (1949) from Switzerland; Knee and Moeller (1967), and O'Neal and Waller (1984) from the USA. In Asia investigations were made for A. cerana Fab. bees in different parts of India on pollen sources in Maharashtra by Deodikar, 1965; Chandran and Suryanarayana, 1970; Suryanarayana, 1975, 1978; Chaudhari, 1977; Singh et al, 1987; Suryanarayana and Singh, 1989. Sharma, 1970 analysed pollen loads collected from Kangra, Himachal Pradesh; and Chaturvedi $(1973,1977)$ studied pollen sources at Lucknow, Uttar Pradesh.

The work on melittopalynological studies in Vidarbha regions of Maharashtra is done by few workers such as Bhusariet. al., (2005) analyzed the pollen of Apis florae of Nagpur district, Borkar (2016) studied pollen of Apis dorsata from Chandrapur district, Cherian et al. (2010, 2011) studied pollen of Apis cerenaindica in Nagpur region and the influence of floral source on chemical properties of honey. The pollen spectrum investigation of Apis florae and Apis dorsata of Bhandara district was conducted by Zingare (2010).

Sakoli Tahsil of Bhandara district has huge agricultural land and pockets of deciduous forest. All three species of genus Apis viz. Apis florea, Apis 
dorsata and Apis ceranaindica are present in wild conditions. However deforestation and indiscriminate use of pesticide leads decline in population of bees in agricultural belt, which adversely affected yield of agricultural crops due to pollination crisis. Hence there is a scope to work on domesticated honeybee, Apis ceranaindica that would provide valuable information about its suitability of rearing. The economically and agriculturally backwardness of Bhandara district could be minimized through the rearing of domesticated honey bee which will provide supplementary income to marginal poor farmers directly and increasing the crop productivity through bee-pollination. The information on bee plant interaction is of vital importance in planning programs of apiculture research and development. The pollen load investigation would provide valuable information about the status of beekeeping, potentials of bee resources and seasonal availability of bee forages and importance of individual species on the bee management in Sakoli tehsil of Bhandara district.

\section{METHOD AND MATERIAL:}

Total 87 pollen load were collected carefully with the help of forcep from $7 \mathrm{comb}$ of domesticated honey bee $A$. ceranaindica from Sakoli Tahsil of Bhandara district. Botanical surveys of the areas have been made and observations were made and reference slides of pollen were prepared following the methods of Erdtman (1952). Pollen load were picked up from honey comb of brood chamber of wooden hive of A.ceranaindica f. designated as comb load .The pollen load were found to be stacked one above another in the pollen storing cell of the hive. Sampling was performed once a week. Total 87 pollen load collected from 7 combs of Sakoli Tahsil in 2 years of study from November 2014 to March 2016. To identify the pollen sources, small amounts of pollen from different parts of each pollen load sample were transferred on to a glass slide by a needle and a temporary mount was made. The mount was examined microscopically for pollen contents. Identification of the pollen species was confirmed by comparing these with the pollen in the reference pollen slides.

\section{RESULTS AND DISCUSSION}

Total 87 pollen load collected from 7 combs of Sakoli Tahsil, out of these 61 (70.11\%) pollen loads were found to be unifloral, $8(9.19 \%)$ pollen loads found to be bifloral and multi floral pollen loads were found to be $18(20.68 \%)$.

Out of the 61 unifloral pollen loads 22 have pollen of Coriandrum sativum, 10 contained Brassica sp., 9 have Sesanum indicum, 6 have each Cajanus cajan and Lathyrus sativus, 5 contained Capsicum annuum, 2 contained Alternanthera sessilis and 1 contain Solanum sp. pollen loads.

Out of 8 bifloral pollen loads 2 contained Sesanum indicum and Cajanus cajan, 2 contained Sesanum indicum and Coriandrum sativum, 1 contained Coriandrum sativum and Cajanus cajan, 1 contained Capsicum annuum and Solanum sp., 1 contained Solanum sp. and Sphaeranthus indicus. 1 contained Coriandrum sativum and Brassica sp.,

Whereas Coriandrum sativum, Brassica sp., Parthenium hysterophorus, Solanum sp., Sesanum indicum, Cajanus cajan, Prosopis juliflora, Acacia nilotica, Sonchus oleraceus, Tridax procumbens, Phaseolus sp., Alternanthera sessilis, Lathyrus sativus, Capparis grandis, Capsicum annuum and Sphaeranthus indicus were the pollen type recorded from multifloral load in various combination of 4 to 5 types each On the whole 16 pollen types referable to 9 families were obtained from pollen load of Sakoli Tahsil.

Sakoli Tahsil is a predominantly agricultural area of the district. The important annual crops which provide pollen sources in winter season are Brassica sp., Sesamum indicum, Coriandrum sativum, Cajanus cajan, Capsicum annuum, Lathyrus sativum, Phaseolus sp. and Solanum sp. These contribute to the seasonal pollen sources in winter. 
They are grown as oil seeds, pulses, vegetable crops and spice crops by farmers. Acacia nilotica, Capparis grandis and Prosopis juliflora are grown in wild on waste land and roadsides prove to be good sources of pollen. All these plants are important sources for both nectar and pollen. Alternanthera sessilis, Parthenium hysterophorus, Sonchu soleraceus, Sphaeranthus indicus and Tridax procumbens grows as weeds are also good sources of pollen to $A$. ceranaindica. Coriandrum sativum, Cajanus cajan and Alternanthera sessilis during winter are considered chief pollen source to honeybees while Solanum sp., Capsicum annuum, Sesanum indicum, Brassica sp. and Parthenium hysterophorus are considered significant pollen source.

The study on analysis of pollen loads from other part of India also indicate dominance of unifloral pollen loads over other types and it was concluded that the bees prefer to visit a single source for pollen procurement. However, bees make every effort to meet their food requirement even from more than one source (Sharma 1970; Chaturvedi and Sharma, 1973; Chaturvedi, 1977).

\section{REFERANCE :}

Betts A.D. (1935): The constancy of the pollen collecting bee. Bee World 16, 111-113

Bhusari N. V., Mate, D. M. and Makde, K. H. (2005): Pollen of Apis honey from Maharashtra, Grana Vol. 44:216-224.

Borkar L. N. (2016): Melittopalynological investigation of Apisdorsata hives collected from Chandrapur district of Maharashtra state. Ph. D. Thesis, RTM Nagpur University, Nagpur

Chandran K. and Suryanarayana M. C. (1970): A note on entomophily in Dendrophthoefalcata and its usefulness to the Indian honeybee. $\mathrm{J}$ Apic Res 9, 45-47

Chaturvedi M. (1973): An analysis of honeybee pollen loads from Banthra, Lucknow, India. Grana 13, 139-144
Chaturvedi M. (1977): Further investigation on the pollen analysis of bees loads from Banthra, India. New Bot 4, 41-47

Cherian K. J., Bhowal M. and Godghate S. (2010): Influence of floral source on chemical properties of honey. Essence (International Journal for Environmental Rehabilitation and Conservation) Vol. 1 (2): 72-76.

Cherian K. J., Bhowal M. and Godghate S. (2011): Pollen and physicochemical analysis of honey produced by Apiscerenaindica of Nagpur, Maharashtra. Gerad (Journal of Environmental Resources and Development) Vol. 5 (3): 542550.

Crane E. (1975): Honey: A comprehensive survey. Heinemann. London: 726.

Deodikar G.B. (1965): Melitto-palynology. Indian Bee J 27, 59-72

Knee W.J., Moeller F.E. (1967): Comparative study of pollen sources of honeybees and bumble bees. J Apic Res 6, 133-138

Louveaux J. (1954): Étudessur la récolte du pollen par les abeilles. XV IntBeekeepCongr, Copenhagen

Louveaux J. (1958): Recherchessur la récolte du pollen par les abeilles (Apismellifica L). Ann Abeille 1, 113-188, 197-221

Maurizio

A.

PollenanalytischeUntersuchungenanHonig und Pollenhöschen. BeihSchweizBienenztg 2, 320455

O'Neal R.J., Waller G.D. (1984): On the pollen harvest by the honey bee (Apismellifera L) near Tucson, Arizona (1976-1981). Desert Plants 6, 81-94, 99-109 (AA 558/1986)

Percival M. (1947): Pollen collection by Apismellifera. New Phytol 46, 142-173

Ramanujam C. G. K. and Khatija, F. (1992): Summer pollen sources to Apisdorsata honeybees in deciduous forest of Mahboob Nagar District, A.P. Geophytology Vol. 21 : 155-161. 
Sharma M. (1970): An analysis of pollen loads of honey bees from Kangra, India. Grana 10, 3542

Singh T.S.M.S., Joshi M.A., Suryanarayana M.C. (1987): Evaluation of sources of pollen to honey bees at Vijayarai (Andhra Pradesh). Proc 5th All India SympPalynol, Nagpur, India, 65-71

Suryanarayana M.C. (1975): Studies on bee botany and palynology of the flora and coorg and adjacent parts of the Mysore State. Ph D thesis, Poona University

Suryanarayana M.C. (1978): Bee plants of India. 1. Carviacallosa (Nees) Brem. Indian Bee J 40, 710
Suryanarayana M.C., Singh T.S.M.S. (1989): Partheniumhysterophorus - a pollen source to Apismellifera. Bee World 70, 127-129

Synge A.D. (1947): Pollen collection by honey bees. $\mathrm{J}$ AnimEcol 16, 122-138

Zingare A. K. (2010): Melittopalynological investigation of honey collected from Sakoli and Lakhanitalukas of Bhandara district with reference to Apis florae hives and Apisdorsata hives. Ph. D. Thesis, RTM Nagpur University, Nagpur.

Table 1 : Analysis of Winter Pollen Loads of Sakoli Tahsil

\begin{tabular}{|c|c|c|c|c|c|c|c|}
\hline \multirow[b]{2}{*}{ Comb. No } & \multirow[b]{2}{*}{ 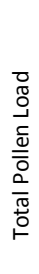 } & \multicolumn{2}{|c|}{ Unifloral Load } & \multicolumn{2}{|c|}{ Bifloral Load } & \multicolumn{2}{|r|}{ Multifloral Load } \\
\hline & & 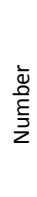 & 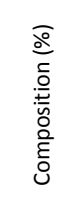 & 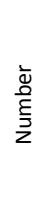 & 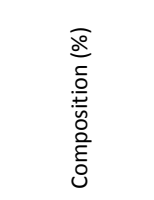 & 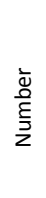 & 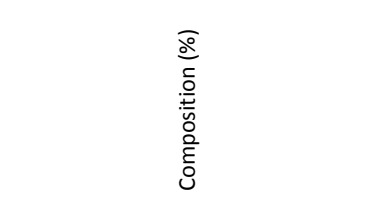 \\
\hline $\begin{array}{l}\text { BHA-SAK-KIN- } \\
\quad 33\end{array}$ & $\begin{array}{l}1 \\
1\end{array}$ & 8 & $\begin{array}{l}\text { 6-Cori } \\
\text { 2-Bra }\end{array}$ & 1 & $\begin{array}{l}1-\operatorname{Cor}(53) \\
\operatorname{Bra}(47)\end{array}$ & 2 & $\begin{array}{l}\text { 1-Cor(54), } \operatorname{Bra}(37), \operatorname{Par}(7) \operatorname{Sol}(2) \\
\text { 1-Cor(49), } \operatorname{Bra}(42), \operatorname{Par}(6) \operatorname{Sol}(3)\end{array}$ \\
\hline $\begin{array}{l}\text { BHA-SAK-SAK- } \\
\quad 36\end{array}$ & $\begin{array}{l}1 \\
0\end{array}$ & 6 & $\begin{array}{l}\text { 3-Ses } \\
\text { 3-Caj }\end{array}$ & 2 & $\begin{array}{l}2-\operatorname{Ses}(51)(54) \\
\operatorname{Caj}(49)(46)\end{array}$ & 2 & $\begin{array}{l}\text { 1-Ses(71)Caj(20)Bra(4)Pro(3)Son(2) } \\
\text { 1-Ses(49)Caj(39)Bra(8)Alt(3)Aca(1) }\end{array}$ \\
\hline $\begin{array}{l}\text { BHA-SAK-KIN- } \\
\quad 38\end{array}$ & $\begin{array}{l}1 \\
1\end{array}$ & 8 & 8-Bra & Nil & -- & 3 & $\begin{array}{c}\text { 1-Bra(72)Tri(20)Pha(6)cap(2) } \\
\text { 1-Bra(69)Tri(16)Pha(11)Alt(4) } \\
\text { 1-Bra(58)Tri(28)Pha(8)Alt(6) }\end{array}$ \\
\hline $\begin{array}{l}\text { BHA-SAK-SAK- } \\
40\end{array}$ & $\begin{array}{l}1 \\
1\end{array}$ & 9 & $\begin{array}{l}\text { 6-Lat } \\
\text { 3-Cor }\end{array}$ & Nil & -- & 2 & $\begin{array}{c}\text { 1-Lat( 47)Cor(29)Bra(13)Par(8)Sol(3) } \\
\text { 1-Lat(5) Cor(33)Bra(11)Par(5) }\end{array}$ \\
\hline $\begin{array}{l}\text { BHA-SAK-SAN- } \\
42\end{array}$ & $\begin{array}{l}1 \\
1\end{array}$ & 9 & $\begin{array}{l}\text { 6-Ses } \\
\text { 2-Cor } \\
1 \text {-Caj }\end{array}$ & 2 & $\begin{array}{l}2-\operatorname{Ses}(63)(67) \\
\operatorname{Cor}(37)(33)\end{array}$ & Nil & -- \\
\hline $\begin{array}{l}\text { BHA-SAK-SAN- } \\
48\end{array}$ & $\begin{array}{l}1 \\
1\end{array}$ & 8 & $\begin{array}{l}\text { 6-Cor } \\
\text { 2-Alt }\end{array}$ & Nil & -- & 3 & $\begin{array}{l}\text { 1-Cor(77)Caj(8)Alt(7)Capp(5)Tri(3) } \\
\text { 1-Cor(75)Caj(11)Alt(9)Capp(3)Tri(2) } \\
\text { 1- Alt(58)Caj(25)Cor(15)Cel(2) }\end{array}$ \\
\hline $\begin{array}{l}\text { BHA-SAK- } \\
\text { KINHI-69 }\end{array}$ & $\begin{array}{l}1 \\
1\end{array}$ & 7 & $\begin{array}{l}\text { 5-Cor } \\
\text { 2-Caj }\end{array}$ & 1 & $\begin{array}{l}1-\operatorname{Cor}(62) \\
\operatorname{Caj}(38)\end{array}$ & 3 & $\begin{array}{l}\text { 1-Cor(67)Caj(28)Par(3)Alt(2) } \\
\text { 1-Cor(71)Caj(23)Par(5)Alt(1) } \\
\text { 1- Caj(54)Cor(39)Alt(4)Par(3) }\end{array}$ \\
\hline $\begin{array}{l}\text { BHA-SAK-SAN- } \\
71\end{array}$ & $\begin{array}{l}1 \\
1\end{array}$ & 6 & $\begin{array}{l}\text { 5-Cap } \\
\text { 1-Sol }\end{array}$ & 2 & $\begin{array}{l}\text { 1-Cap(80) } \\
\text { Sol(20) } \\
1-\operatorname{Sol}(72) \\
\text { Sph(28) }\end{array}$ & 3 & $\begin{array}{c}\text { 1-Cap(62)Sol(25)Sph(8)Bra(4)Caj(1) } \\
\text { 1-Sol(60)Cap(21)Sph(14)Bra(5) } \\
\text { 1-Cap(63)Sol(27)Sph(8)Caj(2) }\end{array}$ \\
\hline
\end{tabular}

Abbreviations for pollen types recorded from honey combs

Acn-Acacia nilotica, Alt-Alternantherasessilis, Bra-Brassica sp., Caj-Cajanuscajan, Cap-Capsicum annuum, Cpp-Capparisgrandis, CorCoriandrumsativum, Lat-Lathyrussativum, Par- Partheniumhysterophorus, Pha- Phaseolus sp., Pro-Prosopisjuliflora, SesSesanumindicum, Sol-Solanum sp., Son- Sonchusoleraceus, Sph-Sphaeranthusindicus, Tri-Tridaxprocumbens. 
Fig 1 Photomicrographs of some pollen grains (x400) of some bee plants at Sakoli Tahsil of Bhandara district.
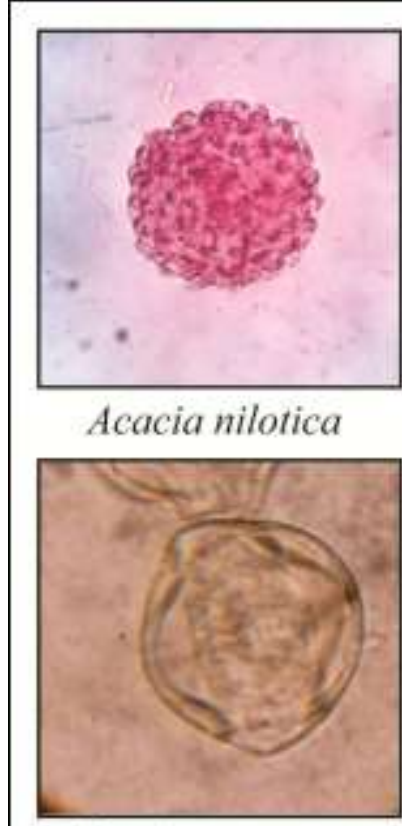

Capsicum annum

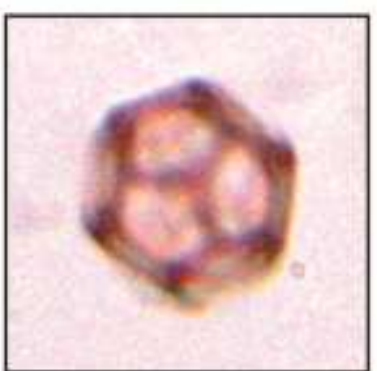

Alernanthera sisilis

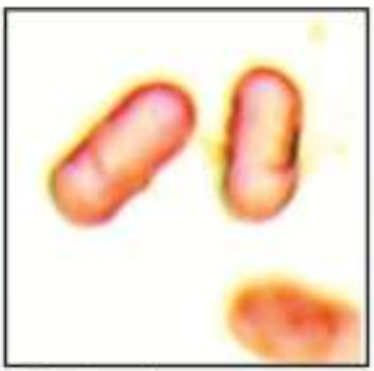

Coriandrum sativum

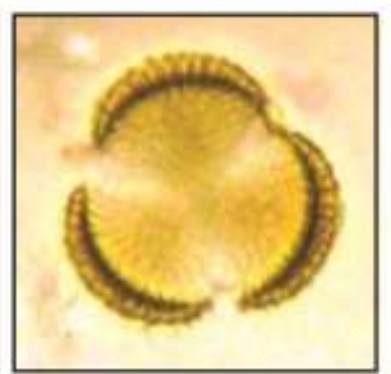

Brassicasp.

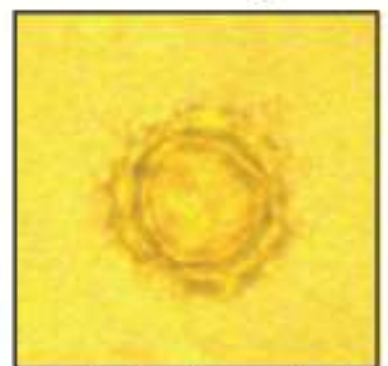

Parthenium hyserophorus

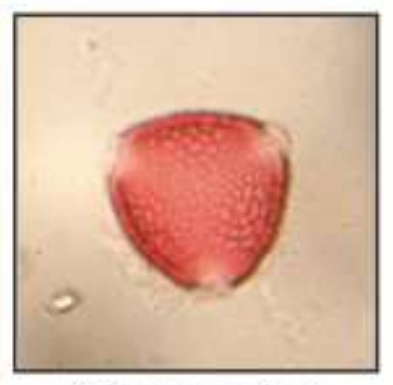

Cajanus cajan

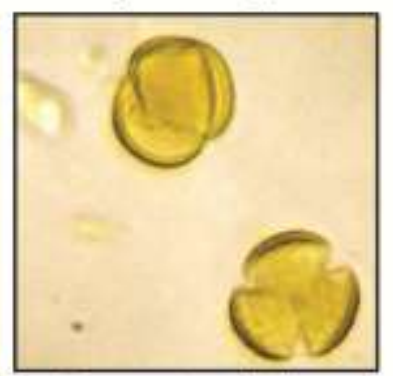

Prosopis julifera

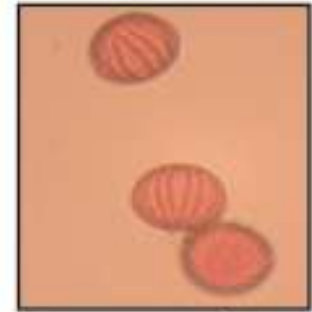

Sesanum indicum

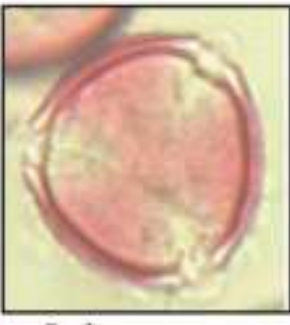

Solamum sp.
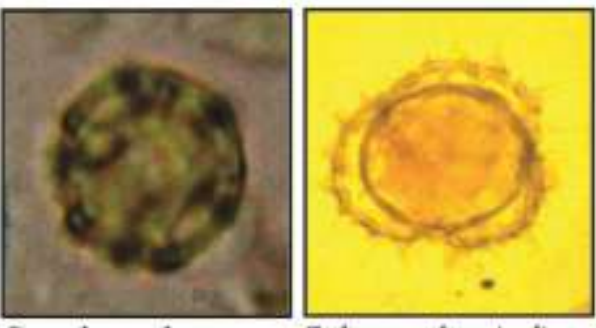

Sonchus oleraceus Sphaeranhus indicus Tridax procumbens

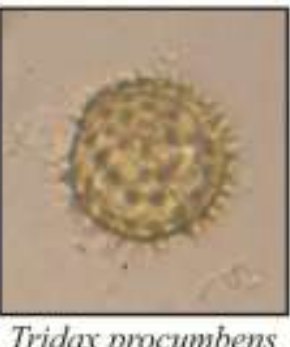


